\title{
Mulemba
}

Revista Angolana de Ciências Sociais

6 (11) | 2016

Políticas, direitos e práticas da sociedade e do Estado

\section{A transformação da história em processo: Da perspectiva utópica da filosofia da história à Revolução Francesa de Koselleck}

\section{Cesaltina Abreu}

\section{(2) OpenEdition \\ Journals \\ Edição electrónica \\ URL: http://journals.openedition.org/mulemba/1694 \\ DOI: $10.4000 /$ mulemba.1694 \\ ISSN: 2520-0305 \\ Editora \\ Edições Pedago}

\section{Edição impressa}

Data de publição: 1 maio 2016

Paginação: 351-367

ISSN: 2182-6471

\section{Refêrencia eletrónica}

Cesaltina Abreu, «A transformação da história em processo: Da perspectiva utópica da filosofia da história à Revolução Francesa de Koselleck», Mulemba [Online], 6 (11) | 2016, posto online no dia 13 outubro 2018, consultado o 27 janeiro 2021. URL: http://journals.openedition.org/mulemba/1694 ; DOI: https://doi.org/10.4000/mulemba.1694 


\section{A transformação da história em processo: Da perspectiva utópica da filosofia da história à Revolução Francesa de Koselleck*}

\section{Cesaltina Abreu**}

Uma das ideias centrais do autor, neste livro, consiste na busca de uma explicação da natureza do mundo actual a partir da dinâmica do iluminismo e da consequente génese do mundo burguês.

A sociedade burguesa que se desenvolveu no século xvinI na Europa recém pacificada das lutas religiosas e das consequências da reforma, desenvolveu uma filosofia da história em cujo centro se encontrava toda a humanidade, que deveria, através da sua liderança, caminhar para um futuro melhor. Havia um sentido utópico de unidade do mundo; segundo o autor, esta ideia de unidade serve de esteio às projecções do mundo contemporâneo (à época da publicação do livro), marcado pela dicotomia dos blocos que caracterizou o período da guerra fria. De igual modo presente, também nesse contexto, a ideia de liderança: ambos os blocos reivindicavam

* Recensão a obra de Reinhart KoselLEck, Crítica e crise. Uma contribuição à patogénese do mundo burguês. Traduzido do original alemão por Luciana Villas-Boas Castelo-Branco. Rio de Janeiro, Contraponto Editora e Ed-UERJ, Editora da Universidade do Estado do Rio de Janeiro, 1999, 256p.

** Socióloga, Professora Auxiliar e Chefe do Departamento de Sociologia da Faculdade de Ciências Sociais (FCS) da Universidade Agostinho Neto (UAN) e docente convidada do Curso de Mestrado em Ordenamento e planeamento de áreas urbanas do Departamento de Arquitectura da Faculdade de Engenharia da UAN. 
a liderança do mundo em direcção a um futuro melhor, ao mesmo tempo que, reciprocamente, procuravam evitar quebrar um, ainda que frágil, equilíbrio de forças entre eles: é a complementaridade dos seus papéis que produz a ideia de unidade do mundo.

Para Koselleck, tal situação reproduz a função da filosofia da história produzida pelo iluminismo: com base no argumento da unidade do mundo, a acção interna da burguesia foi corroendo o sistema absolutista, que condicionou a génese do iluminismo. Por esse motivo, o significado político do iluminismo constitui o tema central deste trabalho, visando esclarecer a função política do seu pensamento e as aspirações da burguesia no âmbito do estado absolutista.

O património de ideias e aspirações construído pelos cidadãos durante a vigência do estado absolutista foi retomado, numa determinada situação, e reinterpretado pelos iluministas em termos de filosofia da história. O estudo deste movimento das ideias interessa ao autor na medida em que permite estabelecer a sua relação com os eventos políticos que marcaram a história da humanidade, ou seja, as ideias importam sempre que seja possível desvendar seu sentido e suas consequências: por isso, o método usado recorre à análise da história das ideias e sua contextualização, em termos das circunstâncias sociológicas em que se constituíram e revelaram.

As circunstâncias que viabilizaram o desenvolvimento político do iluminismo - a progressiva perda de poder e de prestígio por parte do estado francês e o seu crescente envolvimento com práticas de corrupção, enquanto o monarca, apesar de manter a soberania, mostrava-se cada vez menos eficaz na imposição de suas vontades e decisões - surgem num percurso caracterizado pela continuidade de condições gerais: o sistema absolutista manteve-se até à revolução, apesar de ter perdido para o iluminismo alguns de seus representantes.

Ao autor interessam todas as fontes, das mais eruditas às mais panfletárias: os denominadores comuns traduzem-se nas abordagens heurísticas que estabelecem a ponte entre a perspectiva utópica da filosofia da história e a revolução francesa, ou seja, estabelecem a relação entre a crítica e a crise a que ela deu origem. A filosofia da história resultou de um rigoroso e amplo processo de crítica que simultaneamente se materializava em efervescência social; a articulação da oposição entre antigo e moderno, e da separação entre passado e futuro, surge primeiramente na crítica da arte, essencialmente literária, para se estender a todos os domínios da 
vida, julgados pelo alto tribunal da razão à luz da filosofia histórica, através da qual os críticos burgueses transformaram a história em processo. Contudo, os principais alvos eram a religião cristã, transformando o plano divino de salvação em planeamento do futuro, e o estado absolutista. Todas as mudanças operadas foram realizadas pela crítica burguesa sem a consciência, no acto, não só do seu protagonismo colocando-se sempre ao lado do progresso, mas também do alcance desse movimento das ideias.

$\mathrm{Na}$ perspectiva do autor, a resposta do estado francês às lutas religiosas foi a imposição do estado absolutista como forma de pacificação. A implantação da doutrina da «razão de Estado» permitiu separar a moral da política e da religião, dando à moral amplo espaço de desenvolvimento no foro privado, enquanto esvaziava o conteúdo político da acção dos indivíduos, entretanto livres de vínculos religiosos. Ou seja, ao mesmo tempo que emancipa moralmente os indivíduos, priva-os de responsabilidades (centralizadas na figura do monarca), reduzindo-os ao espaço privado: estão assim criadas as condições para que os indivíduos entrem em contradição com o estado. Este, ao subordinar a moral à política e ao conceber de maneira formal a esfera política, permitiu que tal separação se voltasse contra ele, que passou a confrontar-se com uma série de processos morais. O processo de emancipação dos indivíduos permite um aumento de nível de esclarecimento, um mais profundo entendimento dos conceitos de bem e de mal, e transforma cada cidadão em juiz, cada vez mais identificado com a sua dimensão moral, destituído que estava das suas funções políticas e dos vínculos religiosos. Neste contexto, não só a política, enquanto actividade constante da existência humana, foi relegada para o plano das construções utópicas do futuro, mas também foi tal utopismo condicionado historicamente e fixado na filosofia da história.

Na sequência da crise da ordem tradicional ocorrida no século XVI, durante a qual a igreja perdeu a sua unidade, gerou-se um ambiente de profunda intolerância religiosa que rompeu laços familiares e alianças que davam coesão às famílias, aos povos e às nações; a resposta à crise foi o estado absolutista, restabelecendo a paz e a ordem. Esta resposta traduziu-se em alterações fundamentais nos papéis do soberano e dos súbditos, especialmente na concepção da redistribuição da responsabilidade e da culpabilidade entre si: destituiu-se o súbdito de toda a responsabilidade, arcando com a culpabilidade tanto em relação aos seus actos em oposição aos interesses 
do soberano, quanto em relação à sua consciência. Contrariamente, o soberano era eximido de qualquer culpabilidade, sendo instituído de toda a responsabilidade e coagido a tomar decisões e a agir. Esta obrigatoriedade de agir implicava uma tentativa de avaliação, pelo soberano, das possíveis consequências dos seus actos, o que introduziu um elemento de cálculo racional na política: o desafio do monarca era o de agir sem extrapolar o seu poder que, entretanto, não cessava de ser ampliado em resultado da necessidade de manter sob controle as consequências dos seus actos. $\mathrm{O}$ abuso do poder acelerou o desenvolvimento do iluminismo que, nascido do absolutismo, iria ser o seu algoz. Neste processo de desenvolvimento do movimento das ideias, o súbdito transformava-se em cidadão e iria provocar a derrocada do sistema.

A doutrina da «razão de Estado» que subentende a submissão de todas as consciências, inclusive a do soberano, ao interesse estatal, operou uma separação entre política e moral, criando um espaço livre de prescrições morais, onde a política pode se desenvolver sem intervenção da moral. Tal separação resulta da estrutura política do iluminismo, em que coexistem: o caráter estamental da organização social tradicionalista, uma esfera de acção supra-religiosa e estatal, e um monarca com poder absoluto que não reconhecia nenhuma instância superior a si próprio, assumindo-se «Deus na terra», operando no espaço político e histórico. Entre a base da sociedade e o soberano instalou-se um vazio, após a extinção ou neutralização de todas as instituições autónomas.

$\mathrm{Na}$ análise deste percurso, o autor dialoga com Hobbes, Locke, Leibniz e Rousseau, entre outros. Para analisar a constituição e legitimação do poder absolutista, o autor retoma Thomas Hobbes, antropologista individualista que vivenciou a experiência das lutas religiosas em França e que defendia um discurso da ordem com um traço conservador, salientando a dificuldade de sustentação dos vínculos sociais, políticos e religiosos devido à própria natureza humana, egoísta e perseguindo as suas paixões; como na natureza tudo é passível de posse, resulta o estado de guerra de todos contra todos, em que o direito de todos prevalece sobre todos. Nele, a explicitação de pensamentos e ideias joga um papel central na construção da consciência e da própria razão, daí a importância fundamental da linguagem para a construção da sociabilidade. Ao acabar com o estado de guerra, o soberano cria condições para a operação das virtudes morais que todos têm de natureza e perante Deus, mas não 
acaba o conflito, porque a sociedade não funciona assim: partindo da vida como ela é, Hobbes recorre a um viés muito normativo para apontar o «como» ela deveria ser. Equivalendo-se no homem os desejos de poder e de paz, num equilíbrio instável que contém os motivos e as causas das guerras e da paz, ao separar consciência da acção a construção da teoria política de Hobbes tem um pressuposto que é o estado ordenado capaz de tudo fazer para manter a ordem através da obediência de todos e, assim, evitar que a sociedade volte a viver em estado de natureza. Este papel do estado exige a separação entre consciência e acção, moral e política, intenção e prática, numa dicotomia entre público e privado na qual a consciência transforma-se em moral privada e o seu papel é o de garantir que a lei natural, que manda estabelecer a paz, seja cumprida, o que legitima o estado absolutista e a sua estrutura política, dotado da suprema obrigação moral de oferecer protecção a todos, para o que todos deveriam transferir os seus direitos para o soberano que reina sobre todos. A construção do estado tem como pilares não só a protecção como obediência, constituindo-se em «juiz racional dos homens irracionais», mas também o soberano, com as funções políticas de instaurar e manter a ordem.

A dicotomia entre público e privado e entre responsabilidade e culpabilidade permite que o homem se remeta às suas convicções, num espaço que foi progressivamente alargado pelo desenvolvimento do iluminismo, encobrindo as pretensões de intervenção do individuo em domínios reservados ao estado. Para se ilibar da prestação de contas por tal pretensão, ele recorre ao segredo e à mistificação, reservando para o foro íntimo da convicção as pretensões que lhe são vedadas enquanto participante no mundo da política, no qual ele é subordinado ao soberano e, como tal, é só como súbdito que ele é cidadão; como homem, apenas é livre no foro íntimo.

O facto de apenas interessar ao soberano a subordinação e a obediência do súbdito, não se preocupando com o seu foro íntimo nem com a sua vida privada, constituiu, segundo o autor, o espaço e a oportunidade que vai ser aproveitado pelo desenvolvimento do movimento das ideias: a perda do carácter de necessidade do estado, uma vez instalada e mantida a paz, a razão do estado torna-se imoralidade, sentimento que se vai acentuando em função do desenvolvimento do foro íntimo dos homens, que viam na sua condição de súbditos a única qualidade política reconhecida pelo estado. 
Se a ordem política supra-religiosa permitiu a pacificação dentro dos estados, ela marcou igualmente o quadro das relações internacionais: houve um deslocamento da guerra para o exterior dos estados. $\mathrm{O}$ «estado de natureza» de Hobbes, ultrapassado pela instalação do sistema absolutista, transfere-se para as relações entre os países, entendidos como «homens grandes».

Chamando Vattel $^{1}$ para o diálogo, Koselleck considera que a guerra tornou-se um instrumento permanente de política dos príncipes com o objectivo de evitar a guerra civil. A analogia da construção reside em que assim como no estado de natureza os homens são submetidos apenas à sua própria consciência, as nações, livres e independentes, apelavam à consciência da nação ligada à lei natural submetida ao direito interno. Também aqui se fazia presente a necessidade de um mandamento moral unívoco da paz e para dar conta desta necessidade, esboçou-se o droit des gens volontaire, um direito externo que funda as regras de uma moral da acção internacional, essencialmente política, que convive, lado a lado, com o droit des gens necessaire, o direito interno, ambos fundados na razão. ${ }^{2}$ A instauração da ordem de paz surge quando o droit des gens volontaire, o direito externo comportando as regras de um âmbito político isento de argumentação moral, prevalece sobre o droit des gens necessaire, ao qual se submetia apenas a consciência do soberano, ou seja, quando as leis morais se subordinam às necessidades políticas.

Os tratados de paz de Westfalia e de Utrecht, instâncias na solução de questões originadas pelos conflitos religiosos, que estabeleceram o princípio de equilíbrio europeu vinculando todas as nações europeias à defesa da integridade territorial de cada uma delas, conduziram a uma situação de equilíbrio resultante da neutralização política dos conflitos religiosos e da esperança que também as guerras entre estados viessem a ser progressivamente eliminadas.

Dialogando com Schiller, ${ }^{3}$ o autor considera que este equilíbrio, fundado no desdobramento da moral, abriu o espaço social em que

1 Emer de Vattel (1714-1767), filósofo e diplomata suíço.

2 Hugo Grotius (1583-1645), jurista, filósofo, dramaturgo e poeta dos Países Baixos. Em De jure belli ac pacis (Du droit de la guerre et de la paix), 1625, criou os fundamentos do Direito Internacional, fundado no Direito Natural.

3 Johann Christoph Friedrich von Schiller (1759-1805), poeta, filósofo e historiador alemão. 
a nova elite pôde desenvolver-se num sentido em que conduzia ao desmacaramento de uma estabilidade alcançada através da subordinação da moral às necessidades políticas: este sentido de dupla moral tornou insuportável, para os defensores de um direito natural unificado e unificador, a aceitação de um domínio de decisão livre nas mãos do monarca. A política absolutista que repousava nas dicotomias entre interior e exterior, entre o continente e os outros, entre estado e indivíduo e entre homem e cidadão, foi questionada em toda a parte por uma perspectiva universalista de moral, tecida no desenvolvimento do movimento das ideias, o que justifica que, da Europa, esta contestação se tenha espalhado pelo mundo, favorecendo o auto-entendimento da burguesia emergente.

Na perspectiva do autor, a acção da burguesia emergente expandiu o foro interior privado para o domínio público, que se transforma num fórum permeando toda a sociedade, deslocando os limites estabelecidos pelo estado absolutista. Para comprovar a sua tese, Koselleck analisa o caso da burguesia inglesa, a primeira segundo ele a manifestar os traços característicos da actividade extra-estatal de julgar, constitutiva da burguesia. O esteio da discussão é fornecido pela obra de John Locke, ${ }^{4}$ apelidado de «pai espiritual do iluminismo burguês», principalmente pelo Ensaio acerca do entendimento humano, no qual trata das leis que deveriam orientar a vida dos cidadãos. Para Locke tais leis eram de três tipos: a lei divina, regulamentando o que é pecado e o que é dever e que se manifesta pela natureza ou pela revelação; a lei civil que regulamenta o crime e a inocência, lei estatal instrumentalizada pela coerção com o objetivo de proteger os cidadãos; e a lei moral, que mede o vício e a virtude. Esta última, também designada da «lei da opinião ou da reputação", originada no foro interior da consciência humana, foi excluída por Hobbes do domínio da acção do estado: apesar de os cidadãos não terem qualquer poder político, eles possuem o poder espiritual do juízo moral, que estabelece os limites da virtude e do vício. Ao conferir-lhe um carácter de lei, Locke provoca um alargamento dos limites da moral da convicção de Hobbes, ao mesmo tempo que desloca do cidadão para a sociedade a tarefa de zelar pela

4 John Locke (1632-1704), filósofo inglês ideólogo do liberalismo. No Ensaio acerca do entendimento humano (1690), Locke aborda a origem e a natureza do conhecimento. 
«moral secreta», através do desenvolvimento das suas próprias leis morais, que se colocam lado a lado com as leis do estado tornandose, deste modo, públicas.

$\mathrm{O}$ «acto de julgar», por sua vez, funda-se no acto de vontade dos cidadãos em atribuírem um valor moral às acções pelo elogio ou pela censura - razão pela qual esta lei também é conhecida como «lei da censura privada» -, expresso nas opiniões formuladas pelos cidadãos no espaço privado, mas manifestadas no espaço público. A negação de espaço público aos cidadãos, imposta pelo absolutismo, deslocou a expressão da opinião pública para grupos ou sociedades mais ou menos restritos, onde os cidadãos circulavam e expressavam as suas opiniões. São estes grupos, clubes e sociedades que dão origem ao movimento intelectual que usa a censura como arma e luta pela sua exposição no espaço público. A estratégia destes grupos e sociedades centrava-se no recurso ao segredo como garantia de protecção e reforço da coesão entre «pares»; o seu poder residia na autonomia do juízo dos cidadãos e exercitava-se através da formulação permanente da censura, o que tinha como consequência a transformação das opiniões privadas em leis de carácter obrigatório e universal.

A dupla submissão das acções públicas dos cidadãos à instância estatal (Hobbes) e à instância moral privada (Locke) opera uma ruptura na ordem absolutista, levantando o debate sobre a relação entre legislação privada e legislação pública, colocando em aberto a questão complementar de quem teria a competência para legislar. Deixando sem resposta direta esta questão, Locke parece, entretanto, aceitar a possibilidade de colaboração entre a sociedade e o estado. A eficiência da lei moral filosófica de Locke reside na pressão que a opinião pública pode exercer não só sobre o estado quanto sobre a sociedade no seu todo.

O desenvolvimento deste movimento intelectual teve como ac358 tores ou espaços privilegiados, a «república das letras» e as «lojas maçónicas», elementos constituintes da sociedade civil em construção. $\mathrm{O}$ traço comum, que também era o elemento de coesão entre eles, residia na destituição de liberdade política no estado moderno, devido à concentração total do poder no monarca. Os pilares fundadores desta nova sociedade foram construídos a partir de dois grupos sociais: a parte da aristocracia que lutava contra o poder absoluto do rei e a burguesia ascendente. Os primeiros com pouco poder económico mas com prestígio social e alguma influência política 
remanescente, e os segundos com enorme poder económico e um prestígio social alcançado através do enriquecimento (segundo Koselleck, um dos mais importantes impulsos sociais da dialética da moral e da política, resultou da interacção entre o capital financeiro, em posse da sociedade, e o endividamento financeiro crescente do Estado). A eles se juntaram as centenas de milhares de protestantes franceses, forçados ao exílio pelo édito de Nantes, e que se haviam refugiado na Inglaterra e na Holanda. Eles constituíam uma nova camada social, com interesses diversos, por vezes até opostos, mas que partilhavam a destituição política e a falta de espaço nas instituições absolutistas. Esta destituição partilhada deu origem à constituição de uma comunidade de ideias que fundou uma esfera de interesses externa ao estado, na qual os diferentes grupos encontravam um espaço independente, cujo alargamento crescente consistiu no cenário histórico de constituição de uma nova sociedade. Estes espaços, criados no âmbito do estado absolutista com carácter apolítico e atribuições sociais, variavam de cafés a academias, de bolsa de valores aos clubes e salões, das bibliotecas e sociedades literárias a outros tipos de sociedades de agregação de interesses. Estes palcos de exercício permanente da crítica e da censura foram adquirindo cada vez maior expressão política o que levou à sua repressão pelo estado absolutista, que se sentiu ameaçado na sua integridade. A resposta à repressão foi a clandestinidade, com excepção da franco-maçonaria que, embora procurasse contornar as exigências do estado absolutista, construiu a sua sobrevivência em torno do segredo e do mistério relativamente às suas actividades e funcionamento interno. Os seus principais alvos, entendidos como males fundamentais, eram os estados, as ordens sociais e as religiões, males fundamentais resultantes da diversidade humana e fazendo parte da estrutura da realidade histórica, percebidos como inevitáveis. Considerando-se um exemplo disso, tinham como objectivo construir uma sociedade civil tão perfeita que tornasse o estado supérfluo, reduzido a apenas um meio para a sociedade civil e para os homens; em última instância, o seu objectivo consistia em eliminar os males do mundo exterior, o que significava entrar em conflito directo com o estado.

Por sua vez, os «iluminados» do movimento literário da Alemanha, actuavam como descodificadores semânticos dos escritos dos iluministas para as camadas populares, disseminando ideias do pensamento esclarecido, ao mesmo tempo que procuravam minar o 
poder absolutista «por dentro», quer agenciando simpatias e lealdades de funcionários do sistema, quer privando o estado e as igrejas das suas cabeças e trabalhadores mais capazes.

A luta do bem contra o mal protagonizada pelos maçons dissimulava, de facto, a luta da nova sociedade contra o estado: refugiando-se no distanciamento moral da política como condição de uma actividade contra o estado, a maçonaria mantém a sua dimensão política encoberta e protegida, não só pelo segredo, mas também pela aparente ausência de pretensão política. Enquanto as lojas maçónicas actuavam na integração social da elite burguesa, a «república das letras», seguindo a mesma estratégia de auto-defesa para dissimular a pretensão pela soberania, recorre também à delimitação entre interior e exterior para se diferenciar do estado, o qual é submetido à sua censura, através da crítica da arte: esta entra em cena como a antípoda da ordem estabelecida, transformando o mundo num palco de forças opostas.

Principalmente o teatro e a literatura, tornam-se instrumentos poderosos da crítica política, transformando-se em instâncias de julgamento do bem e do mal, separando o justo do injusto, com base no pressuposto absolutista da divisão da realidade histórica entre moral e política: como instituições sociais e instrumentos do reino da moral, logo não eficazes porque não implicavam uma crítica ao estado, o teatro e a literatura ganharam a necessária liberdade, diante das leis temporais, para reflectir a «luz que reflui da parte pensante do povo», submetendo os políticos ao seu juízo.

A expressão «crítica» enquanto «arte de avaliação da matéria de forma adequada» foi estabelecida no século xvinI e inicialmente usada pelos humanistas para relacionar capacidade de julgar e formação erudita. Foi muito usada durante as lutas religiosas, o que ampliou o seu conteúdo polémico, pela separação dos domínios da razão e da revelação. Segundo Koselleck, Pierre Bayle, ${ }^{\mathbf{5}}$ autor dessa separação, ampliou ainda o uso do método crítico a todos os ramos do conhecimento humano e da história, introduzindo uma dimensão de relatividade e transformando a crítica na actividade da razão: ela tornou-se a arte de alcançar, pelo pensamento racional, conhecimentos e resultados justos e correctos. Na «república das letras», cada um é soberano em relação aos outros e, ao mesmo tempo,

5 Pierre Bayle (1647-1706), filósofo e escritor francês. 
sujeito ao juízo de todos. Contudo, a prevalência do caráter racional da crítica impunha-lhe um outro limite (para além do estabelecido entre razão e religião) e que consistia em considerar como «crime» o enfrentamento do estado, de onde resultou a delimitação do seu campo de acção à ciência e ao espírito, de forma conscientemente apolítica, sem se submeter ao estado.

Esta concepção de crítica de Bayle, foi retomada e alterada por Voltaire: ${ }^{6}$ invocando a separação entre o reino da crítica e o estado, praticava crítica política contra o estado e a igreja através da crítica literária, estética ou histórica: aparentemente apolítica e acima da política era, de facto, política. Com base na convicção de que a razão apenas triunfará através da crítica, esta abandona os domínios que lhe eram peculiares, como a arte e a ciência, e adopta as armas da crítica política, assumindo aos poucos o papel que Locke atribuíra à censura moral: tornar-se porta-voz da opinião pública. Para desempenhar este papel, opera-se no interior da sociedade crítica uma separação essencial entre homem e autor, pessoa e opinião, autor e obra: esta separação é o equivalente funcional da separação entre homem e súbdito, constitutiva da ordem absolutista, condição da ausência de ordem da crítica.

Esta supremacia da crítica em relação aos seus iniciadores, que encobria o segredo, e se tornou gradualmente um poder incontrolável e, por isso, revestido de mistério, é também destruída pelo iluminismo, ao abolir todos os tabus, reduzir o monarca à sua condição de homem, alienando-o do seu elemento, a política, transformando-o em alguém que comete violência, exerce tirania e pratica usurpação. O desenvolvimento deste processo de crítica conduz à superação de uns em relação aos outros, cabendo aos primeiros a condução do progresso que se transforma em revolução, à luz da qual o monarca perde a sua função e, em decorrência, a credibilidade, sendo julgado inimigo da humanidade.

Por seu lado, no mundo da crítica assumiam-se as pretensões e os direitos soberanos da crítica em relação ao estado e o seu papel em relação à opinião pública: a crítica pretende estender o seu reino a tudo e a todos - estado, igreja, opinião pública - , tornando-se obtusa e convertendo-se em hipocrisia, elemento constitutivo do

6 François Marie Arouet, mais conhecido como Voltaire (1694-1778), escritor, ensaísta e filósofo iluminista francês. 
mundo burguês nascente e do pensamento dualista que lhe é peculiar.

Na perspectiva de Koselleck, a crise foi determinada e incitada pela crítica na sua hipocrisia, estabelecendo uma relação entre crítica e crise que passa pela tomada indirecta do poder pela burguesia. De acordo com o autor, a natureza da crise pressupõe que uma decisão tenha de ser tomada, embora não se saiba qual, nem quando, nem como; ou seja, a vivência da crise contém em si a certeza de que ela terá um fim próximo, embora se desconheça como e quando ocorrerá tal transformação e qual a sua natureza.

A situação de crise provocada pela crítica burguesa ao estado foi vivenciada nos estados europeus de formas e intensidades variáveis: na Alemanha havia uma clara percepção de uma eventual cisão entre sociedade e estado provocada pela crescente tensão entre moral e política. Apesar do seu carácter minoritário e da sua fragilidade organizativa, as sociedades secretas são perseguidas e declaradas ilegais, sob a acusação de pretenderem criar um estado dentro do estado; a actividade destas sociedades secretas, que se pretendiam acima dos estados soberanos e com a finalidade de os destruir, assim como às igrejas, era considerada como uma conspiração jesuítico-maçónica visando destruir a ordem estabelecida.

A força atribuída a estes pequenos grupos advinha da filosofia da história; eles eram temidos não tanto pelo poder que de facto detinham, mas pelo papel político que desempenhavam e dos prognósticos de eclosão de uma revolução resultante desta posição política em relação ao estado. O grande projecto dos iluminados alemães, legitimado pela filosofia da história e construído em torno da ideia de novo homem, o deus da terra - inspirado na obra de Leibniz - que quer dirigir a história não pela força mas com recurso à razão, é concebido com recurso a ideias rousseaunianas de natureza, a um cristianismo moralizado e concepções de progresso, corren362 tes na época, entre as quais a certeza de concretização do projecto. Ou seja, a decisão de acabar com o estado absolutista, implícita no grande projecto, não é tomada, mas a sua concretização já está assegurada pelo acto de vontade dos seus mentores: embora planeada e desejada indirectamente, a eliminação do estado far-se-á por si, não sendo necessária nenhuma decisão imediata para o conseguir. A não tomada de decisão teve como resultado um aumento da tensão entre estado e sociedade, pois a dualidade entre moral e política absolvia-os enquanto rebeldes que conspiravam contra a ordem 
estabelecida, na medida em que a filosofia da história permitia-lhes intensificar moralmente o combate ao mesmo tempo que o encobriam politicamente.

Na perspectiva de Koselleck, o prognóstico da revolução - contido no livro de um antigo oficial do exército prussiano que, constituindo um alerta aos príncipes, apresentava uma predição de revoluções inevitáveis -, e a sua dissimulação pela filosofia da história, são dois aspectos da crise. Entretanto a percepção da crise não era generalizada na sociedade, devido à dissimulação pela filosofia do progresso. Quanto aos representantes do estado, alguns tinham noção da incerteza do seu futuro, enquanto outros tinham uma noção do desdobramento das questões morais invocadas em questões políticas fundamentais. Contudo, a decisão política apenas seria concretizada com a revolução francesa.

Na França, ao contrário da Alemanha, a noção de crise latente encontrava-se generalizada e a dissimulação da tensão entre moral e política ainda agravava mais a crise. Para tal, contribuiu a entrada no governo de Turgot, ${ }^{7}$ um jovem que assumiu o Ministério das Finanças e que era produto intelectual da nova sociedade, com um carácter autoritário e pouco conciliador, que percebia o estado de permanente tensão que caracterizava as relações entre os súbditos e o soberano, uns recorrendo a revoltas constantes e o outro à ameaça de guerra civil, num quadro em que a ordem absolutista não dava espaço suficiente à sociedade. Essa percepção levou-o a enfrentar os parlamentos e o monarca, ao defender a criação de um estado que desse espaço de acção ao pensamento liberal. Enquanto homem político, ele ambicionava eliminar a hostilidade entre governo e sociedade, procurando persuadir o monarca quanto às vantagens da tolerância política e religiosa, advertindo-o de diversas formas, da ameaça da guerra civil; ele havia compreendido o estado de crise que exige a tomada de decisão. A concepção que Turgot tinha de estado e de justiça eram completamente opostas às do absolutismo: ele defendia a necessidade de esclarecimento na condução do estado, um espaço de acção para a burguesia nascente e a prática

\footnotetext{
7 Anne Robert Jacques Turgot (1727-1781), economista francês, estudou na Sorbonne e trabalhou na administração real, inicialmente como Intendente em Limoges, onde chamou a atenção pela aplicação de diversas medidas tendentes a racionalizar a economia. Foi nomeado Ministro-Geral das Finanças do Rei Louis XvI em 1774 e demitido 2 anos depois devido às pressões do clero e da nobreza que viram as suas mordomias em causa.
} 
de livre comércio, advogando uma concepção de direito que considerava ateísta, moral, supra-estatal e válido para todos, independentemente da posição social e dos interesses de cada um. O seu pensamento funcionava no âmbito do dualismo que correspondia a uma tomada indirecta do poder.

Opondo-se a Hobbes ${ }^{8}$ e a Locke no que respeita à relação entre direito e poder, Turgot defendia que ambos eram antípodas um do outro. Na relação entre o dever moral da obediência e o direito político do comando (que constitui a fonte do direito), não poderia, em sua opinião, haver contradição; ele defendia que a verdadeira fonte do direito é a instância moral, a consciência e não o poder estabelecido. Esta era uma posição oposta à de Hobbes, que fundamentava a construção do estado absolutista, e deste ponto de vista, ao agir contra a moral, o monarca comete um pecado perante Deus e diante do tribunal da sociedade.

No âmbito da ausência da tomada de decisão por parte do soberano e de uma ausência do estado à questão colocada por Turgot, ganham sentido, não apenas os conceitos que marcavam o pensamento da nova elite, mas o próprio conceito de soberania, diluindo o poder real de decisão: embora permaneça no governo, Turgot vai suprimindo a estrutura política. O aumento da tensão entre moral e política, explicitada por Turgot, conduziu à sua demissão, que significou o fracasso da última tentativa de satisfazer as necessidades da sociedade de uma maneira indirecta, formalmente no terreno do estado e através de uma aliança com o monarca; aproximava-se a guerra civil, que Turgot tinha procurado evitar porque preferia uma transformação progressista do regime estabelecido.

Concebendo «crise» como um estado de insegurança e incerteza que se abate sobre todos os homens devido à ruptura da ordem estabelecida, Rousseau ${ }^{9}$ prognosticava o advento do estado de crise e do século das revoluções. Entendido por Koselleck como o primeiro democrata, Rousseau criticou estado e sociedade, procurando conceber as relações entre ambos; contudo, ao procurar reunir moral esclarecida e estado, preparou o caminho para a tão temida revolução,

8 Thomas Hobbes (1588-1679), matemático, teórico político e filósofo inglês, autor do Leviatã e Do cidadão, ambos de 1651.

9 Jean-Jacques Rousseau (1712-1778), filósofo, teórico político, escritor e compositor suiço, autor de Do contrato social (1762), precedido pelo Discurso sobre a origem e os fundamentos da desigualdade entre os homens (1755). 
aplicando a vontade soberana à autonomia moral da sociedade, de onde resulta a vontade geral absoluta, que estabelece a lei para si mesma. Para Rousseau, a nação tem uma vontade geral que faz dela uma nação, mas que não pode realizar-se politicamente de forma directa, na medida em que tal vontade não tem executor, e como não pode ser delegada ou representada, torna-se invisível. Se todos são soberanos, a sociedade estatiza-se, a soberania de Rousseau revela-se uma ditadura permanente. Como cidadão, só participando da vontade geral o indivíduo adquire liberdade, e como Homem ele não sabe «quando» nem «como» seu «eu» interior estará de acordo com tal vontade geral. Enquanto os indivíduos podem enganar-se, a vontade geral jamais se engana, o que dá origem à necessidade de integração dos «enganados» ou "distraídos», através de um processo de correção permanente da realidade que é a ditadura, chamando à cena a figura do "guia» para ajudar a identificar moral com política e a encontrar o bom caminho. A ditadura distingue-se do absolutismo ao incluir o «eu» interior, transformando acções em convicções, com recurso ao terror e à ideologia.

Após o reinado da opinião pública como ideologia do iluminismo, Rousseau propõe a ideologia da censura moral, sendo o censor público o chefe dos ideólogos. Entretanto, tal como no iluminismo, também a ditadura precisa dissimular o seu poder: a maior habilidade do chefe dos censores consiste em ocultar o seu poder e conduzir o povo tão pacificamente como se na verdade isso não fosse necessário, mediante a pressão para a conformidade. Devido à sua instabilidade, ocorre a desagregação da ordem política e instala-se a crise como resultado da ausência de autoridade, que cede lugar à anarquia. Assim, em Rousseau, o estado de crise institui a crise do estado.

A ameaça à soberania do monarca materializada no conflito político entre a nova elite e o estado, permite reconhecer a crise política que exige uma decisão política, dela dependendo se a crise irá desembocar em escravidão ou em liberdade. Segundo Koselleck, a dualidade do prognóstico do fim da crise já se encontra enunciada nas categorias da crítica burguesa: a distinção entre inocência moral e a autoridade transformada em violência imoral, determina a decisão política.

Concluindo, Koselleck afirma que crise e filosofia da história são complementares e intrinsecamente relacionadas, a sua conexão reside no processo crítico que a burguesia moveu contra o estado: da 
crítica origina-se a filosofia da história e esta dá origem à crise. Sendo a incerteza da crise idêntica à certeza do planeamento da história utópica, uma provoca a outra e vice-versa e as duas perpectuam o processo que a burguesia moveu contra o estado absolutista.

\section{Cesaltina Abreu}

Doutorada em Sociologia (2006) e mestre (2001) pelo Instituto Universitário de Pesquisas do Rio de Janeiro (IUPERJ), República Federativa do Brasil. É licenciada em Agronomia (1977) pela Universidade de Luanda (curso superior de Agronomia, Huambo). A sua dissertação de mestrado intitula-se Participação faz diferença? Reflexões na avaliação do Fundo de Apoio Social (FAS) no sudoeste de Angola (Huíla, Namibe e Kunene), e a tese de doutoramento tratou da Sociedade civil em Angola. Da realidade à utopia. Obteve o Certificado em estudos avançados em prática académica (CASAP), Módulos 1 e 2, na Universidade de Newcastle (2013), Grã Bretanha. É actualmente Professora Auxiliar e Chefe do Departamento de Sociologia da Faculdade de Ciências Sociais (FCS) da Universidade Agostinho Neto (UAN) e docente convidada do Curso de Mestrado em Ordenamento e Planeamento de Áreas Urbanas do Departamento de Arquitectura da Faculdade de Engenharia da UAN.

As suas áreas de interesse no âmbito da Sociologia Política envolvem questões multidimensionais da cidadania, análise de contexto, abordagens de "desenvolvimento», sustentabilidade e ambiente, capital humano e social, participação, direitos humanos e justiça social, cultura cívica, espaço público e sociedade civil, memória social, confiança e tolerância. Publicou, entre outros, os materiais seguintes: a) Livro: A actualidade do pensamento de Alexis de Tocqueville na tensão entre igualdade e liberdade e entre indivíduo e sociedade nos processos de democratização contemporâneos (Luanda, Edições Mulemba; Ranada, Edições Pedago, 2015/2016, 110p. [«Cadernos de Ciências Sociais: Série Sociologia»; 3]; b) Em capítulo de livros: "Cidadania e participação em Angola. Que papel para a sociedade civil?», in José Octávio Van-Dúnem e Boaventura de Sousa Santos (orgs.), Sociedade e Estado em construção: Desafios do direito e da democracia em Angola. Luanda e justiça: Pluralismo jurídico numa sociedade em transformação, volume I, Coimbra, Almedina $\mathrm{e}$ CES - Centro de Estudos Sociais da Universidade de Coimbra, 2011, pp. 369-403; "Angola, SADC e a globalização», in Jonuel Gonçalves (org.), Atlântico Sul XXI. América do Sul e África na virada do milénio. São Paulo, Editora Unesp, pp. 185-207; «A sociedade civil em Angola e seus desafios internos e externos», in Nuno Vidal e Justino 
Pinto de Andrade, Sociedade civil e política em Angola. Enquadramento regional e internacional. Prefácio de Patrick Chabal. Luanda e Lisboa, Edições Firmamento e Média xxi, 2008, pp. 101-114; b) Artigos: «Pobreza em Angola: percepções, acção colectiva e os dilemas de participação com base numa pesquisa qualitativa» in Mulemba - Revista Angolana de Ciências Sociais (Luanda), vol. v, n. ${ }^{\circ}$ 9, Maio de 2015, pp. 319-344; «Para uma perspectiva sobre a prática das Ciências Sociais: uma leitura de Charles C. Ragin, Constructing social research: the unity and diversity of method», in Mulemba - Revista Angolana de Ciências Sociais (Luanda), vol. v, n. ${ }^{\circ}$ 9, Maio de 2015, pp. 525-555; "Globalização: Da transformação do espaço social à oportunidade de mudança social», in Mulemba - Revista Angolana de Ciências Sociais (Luanda), vol. Iv, n. ${ }^{\circ}$ 8, Novembro de 2014, pp. 391-420; "Revisitando uma obra exemplar: Dialectic of enlightenment. Philosophical fragments, de Theodor Adorno \& Max Horkheimer», in Mulemba - Revista Angolana de Ciências Sociais (Luanda), vol. Iv, n. ${ }^{\circ}$ 8, Novembro de 2014, pp. 639-656; «Concepções e práticas pedagógicas no ensino das ciências sociais e humanas», in Mulemba - Revista Angolana de Ciências Sociais (Luanda), vol. Iv, n. ${ }^{\circ}$ 7, Maio de 2014, pp. 291-306 (em parceria com Eugénio da Silva e Pedro Manuel Patacho); «Em busca da (re)organização da vida em Angola», comunicação ao I Colóquio da Faculdade de Ciências Sociais da Universidade Agostinho Neto, Luanda, 25-26 Outubro de 2011, in Mulemba - Revista Angolana de Ciências Sociais (Luanda), vol. II, n. ${ }^{\circ}$ 3, Maio de 2012, pp. 103-127; «Desigualdade social e pobreza: ontem, hoje e (que) amanhã?», RAS - Revista Angolana de Sociologia (Luanda), n. ${ }^{\circ}$ 9, Junho de 2012, pp. 93-111.

[e-mail: tinaabreu@yahoo.com.br]

[e-mail: tinaabreu@hotmail.com] 